This item was submitted to Loughborough's Research Repository by the author.

Items in Figshare are protected by copyright, with all rights reserved, unless otherwise indicated.

\title{
Unintended trajectories: liberalization and the geographies of private business flight
}

PLEASE CITE THE PUBLISHED VERSION

PUBLISHER

(C) Elsevier

VERSION

AM (Accepted Manuscript)

LICENCE

CC BY-NC-ND 4.0

\section{REPOSITORY RECORD}

Budd, Lucy C.S., and Brian Graham. 2019. "Unintended Trajectories: Liberalization and the Geographies of Private Business Flight”. figshare. https://hdl.handle.net/2134/5831. 
This item was submitted to Loughborough's Institutional Repository (https://dspace.lboro.ac.uk/) by the author and is made available under the following Creative Commons Licence conditions.

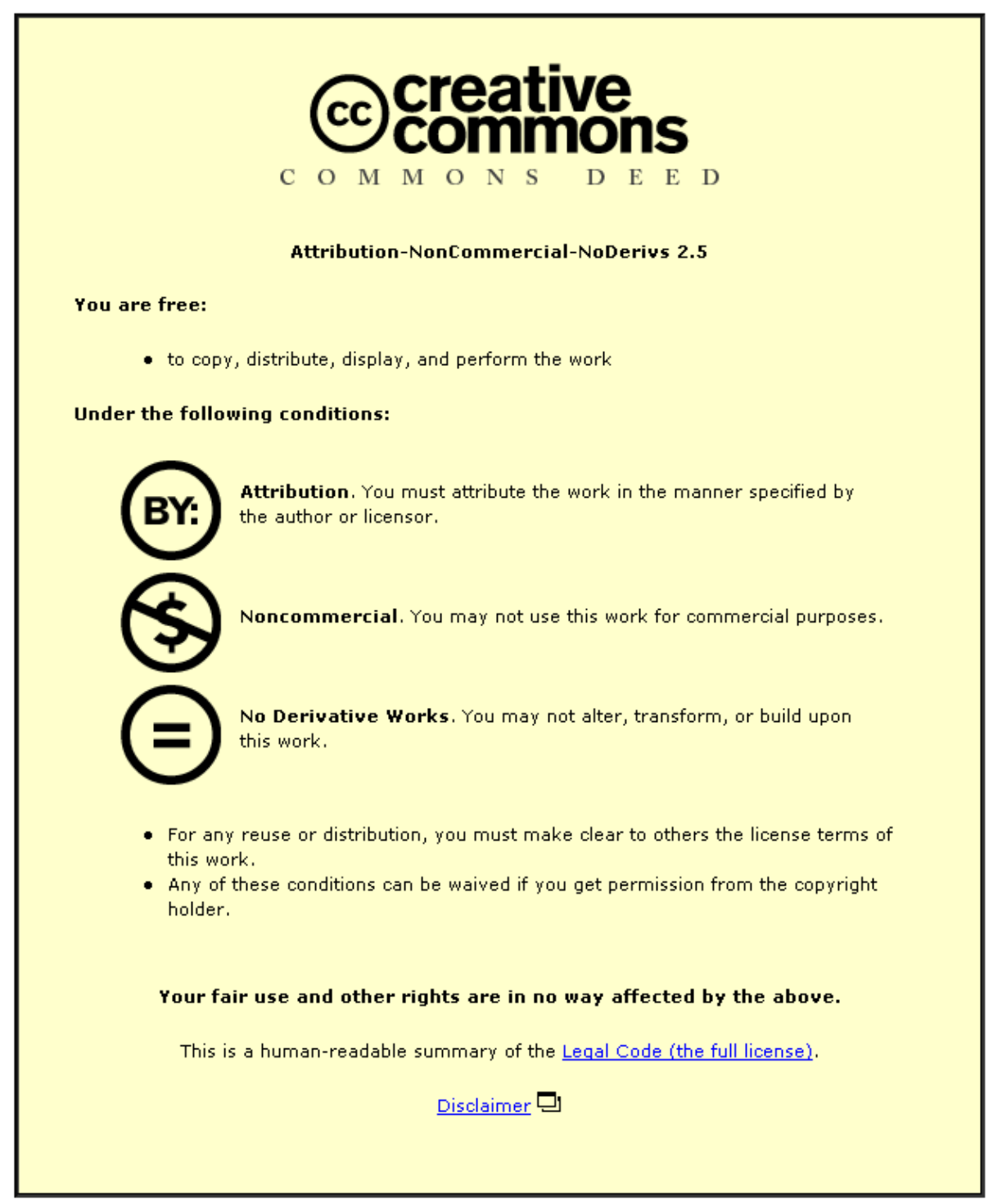

For the full text of this licence, please go to: http://creativecommons.org/licenses/by-nc-nd/2.5/ 


\title{
Please refer to final version of this paper which was published in the Journal of Transport Geography (2009) 17: 285-292
}

\author{
Unintended trajectories: \\ liberalization and the geographies of private business flight \\ L Budd and B Graham
}

\begin{abstract}
The global commercial aviation industry has undergone significant regulatory reform during the last thirty years. This paper explores something of the relationship between air transport liberalization and the growth of private business aviation and suggests that the sector's development is largely an unintended consequence of the increasingly deregulated operating environment in that it has developed to overcome some of liberalization's negative impacts, including delays, congestion, and perceptions of poor customer service. We argue that liberalization has created innovative market opportunities for private business aviation and illustrate how the sector's operating models are facilitating new, as yet largely undocumented, forms of aerial mobility. The paper examines: the advantages of private business aviation over scheduled services; business strategies in the sector, especially the idea of fractional jets; the impact of new technologies, particularly the Very Light Jet (VLJ); and, finally, employs Europe as an example of the spatialities of private business aviation.
\end{abstract}




\section{Introduction}

Historically, the global air transport industry has been heavily regulated, both nationally and internationally, restricting competition and route development. However, since the late 1970s, policies of air transport liberalization have promoted competition by relaxing the rules governing market access, pricing structures, routes, service frequencies and capacity (Doganis, 1994). These policies are now being extended to Asian and African markets. Liberalization refers to 'the exposure of air transport to laissez-faire, or freemarket, forces, achieved through the removal of most regulatory controls over pricing, while permitting carriers to enter and leave markets at will' (Goetz and Graham, 2004, p. 267). The newly liberalised markets, initially domestic but, now, increasingly international, as so-called 'open skies' agreements replace the former restrictive bilateral accords between sovereign states, have resulted in a fundamental restructuring of airline operations. Many airlines have been privatized or partly privatized, networks have been rationalised and reorganised around a number of key hub airports, and carriers have entered into complex code sharing and alliance agreements (Graham, 1995). Although its processes remain unevenly developed and incomplete, in markets where regulatory reform has been enacted, the resulting competitive environment has helped stimulate an unprecedented demand for air travel.

Since the mid-1980s, the number of airline passengers worldwide has doubled to the point where in excess of 2.1 billion people boarded a scheduled flight in 2006 (IATA, 2007). As a consequence, the airline industry is rapidly becoming a victim of its own 
success. Capacity constraints on the ground and in the air combine to cause delays that create large-scale costs for the aviation industry and the global economy through lost productivity (Schumer and Maloney, 2008). Anecdotal evidence suggests that passengers are becoming increasingly dissatisfied with the experience of travelling by air, and the negative environmental externalities of aviation growth are ever more dominating political agendas. It is against this backdrop that we focus on one (largely underresearched) sector of the global air transport industry: business aviation.

In its totality, business aviation encompasses both premium (first- and business-class) airline travel and a dedicated private business aviation sector that operates customised aircraft for (generally) non-scheduled flights. While it accounts for only a small proportion of the total air transport market, business aviation caters to the highest-yield element of that market although as Shaw (2004) argues, yields do not automatically equate to profits as this is also the highest-cost sector for the airlines. Using data from the Association of European Airlines, Derudder and Witlox (2008) have calculated the split between economy class and first/business class travel is around 9:1 (i.e. 90 per cent economy to 10 per cent first/business), although business class traffic is not evenly distributed around the continent and is, instead, focused on major 'business cities' including London, Frankfurt, and Zurich.

The overarching aim of this paper, however, is not to elaborate on airline premium traffic but, instead, to focus on the largely under-researched relationship between air transport liberalization and the growth of private business aviation. This form of aeromobility falls 
under the category of General Aviation and concerns 'the operation or use of aircraft by companies for the carriage of passengers or goods as an aid to the conduct of their business... [and] flown for purposes generally considered not for public hire' (IBAC website, our emphasis). This can include commercial operations (in which a third-party such as a fractional operator or an air taxi service flies the aircraft on behalf of a private client), corporate services (in which corporations own their own aircraft and employ their own flightcrew to fly passengers or goods on company business), and owner-operated aircraft. This definition thus excludes business or first class travel on scheduled airlines, legacy carriers that operate dedicated business class-only services, and business-class only airlines. It should be noted, however, that the distinction between mainline scheduled and business aviation is not altogether absolute. At various times, network carriers have employed business jets to provide hub connections for their premium passengers. The most substantial current example is Lufthansa Private Jet which uses a dedicated business jet fleet to offer both connecting and point-top-point premium flights around Europe (Flight International, 2008).

We argue here that the rapid growth of the private business sector is a direct but primarily unintended consequence of liberalization which has developed to overcome some of the negative aspects resulting from regulatory reform, including delays, congestion, and perceptions of poor customer service. 'Unintended' refers to the opening up of new market opportunities that work out differently from, or are unforeseen by, legislators and, further, the connections between liberalization and technological innovations, which, again, are not necessarily predictable. We begin by demonstrating how liberalization has 
inadvertently created an ideal market in which private business aviation could develop. The paper then considers what we would term 'the hidden geographies of private business aviation', dealing sequentially with: its advantages over scheduled services; business strategies in the sector, especially the idea of fractional jets; the impact of new technologies, particularly the Very Light Jet (VLJ); and, finally, Europe as an example of the spatialities of private business aviation.

\section{Liberalization, fragmentation, and business aviation}

The literature on liberalization has focused largely on its impact upon factors such as scheduled air transport operations, the privatisation of airlines and airports, the commercialisation of airports, and airspace reform. One of the most notable repercussions of liberalization has been the fragmentation of commercial air transport. This term has two different connotations as used here. First, it refers to the network model, advocated for more than a decade by Boeing, which depends on a proliferation of point-to-point connections between a greater number of city-pairs. Such a network geography is a direct repercussion of liberalization and is held to reflect the demand for smaller and more focused individual flows that are, in turn, an outcome of globalisation (Goetz and Graham, 2004). A number of reports further attest to the importance of business aviation to the global economy (for example: Barclaycard, 2006). Air services are considered to be an important driver of globalisation and a catalyst of growth and economic development (see Adey et al, 2007; Urry, 2007; Beaverstock et al, forthcoming). Detailed analyses of international passenger movements have shown how cities are bound into global networks of aerial connectivity with varying degrees of 
centrality, with the global status of key world cities reflected by the position their airports hold within hierarchies of world airports (Smith and Timberlake, 1995; Bowen, 2002; Zook and Brunn, 2005, 2006; Derudder and Witlox, 2008; Lee, 2008). Access to air services is frequently cited as an important factor in deciding where to locate a business, and regions outside the major metropolitan districts are keen to attract airlines to their airports because of the inward investment these services will generate.

Secondly, fragmentation can refer to enhanced market segmentation in air travel.

Drawing on the evidence from other industries which have separated their organisations into distinct business streams offering targeted, differentiated products, Lindstädt and Fauser (2004) argue for a 'separator' approach in air transport that contrasts with the 'integrator' approach of the single production platform of the hub-and-spoke legacy carriers. Dedicated private business aviation is one of the most important forms of market segmentation.

The concept is well established, having originated in the United States after World War One, but it was not until the mid-1930s, when American aircraft manufacturers, including Cessna, Beech, and Piper, began to manufacture light aircraft for the private flyer, that the distinctive genre of private business aviation emerged (Grant, 2003; Sheehan, 2003). Following World War Two, technological innovations in aircraft design and performance made jet-powered business aircraft a viable proposition and the first jet-powered business aircraft, the Lockheed Jetstar, flew in 1957. William Lear's sleek and futuristic-looking jet-powered LearJet followed in 1964, and Learjets quickly became the preferred method 
of travel for celebrities, sportspeople, and the global rich and famous (Grant, 2003). However, high acquisition, maintenance and running costs meant private business aviation remained a luxury obtainable only by a few.

Arguably, the liberalization of the global air transport market was the primary catalyst for both the growth of the business aviation section and, at the other end of the market, of low-cost carriers, another largely unintended consequence. While these latter have been studied extensively (for example: Lawton, 2002; Graham and Shaw, 2008), the growth of the business aviation sector, another direct consequence of liberalization, has remained largely 'hidden' and unobserved. This is, we suggest, partly a consequence of the sector's unique spatial geography, which renders the flights largely 'invisible' to normal flight statistics, and partly a result of the emphasis placed by business aviation operators on client confidentiality and security.

Suppliers of business aviation have responded in different ways to fragmentation. In the first instance, the removal of barriers to market entry and the relaxation of bilateral and multilateral air service agreements have enabled new all-business-class carriers to enter the market, most especially across the North Atlantic. Ultimately, however, high fuel prices combined with insufficient loads seem to have rendered this airline model unsustainable. Since December 2007, three start-ups, Eos, MAXJet and Silverjet have all been declared bankrupt, while Paris-based L'Avion was bought out by British Airways' European subsidiary, 'Open Skies', in 2008 (Robertson, 2008; Werdigier, 2008). Although this suggests that the business-only model is not financially viable, a number of 
legacy carriers, including Lufthansa, Swiss International Air Lines, ANA, British Airways and Singapore Airlines, have been sufficiently concerned by the threat of competition to their highest-yield traffic and convinced of the demand for premium services that they have initiated their own dedicated business-class only operations on various high-yield routes. One example is British Airways' new service from London City Airport to New York planned for 2009. This suggests that it may be the 'stand alone' business-class carrier model that is 'broken' rather than the concept of enhanced market segmentation and demand for premium-class services.

In addition to providing new opportunities and enhanced competition for commercial airlines, market liberalization has also opened up new markets for private business aviation. As demand for air travel has grown, so too has customer dissatisfaction with crowded airports and poor service (Turner, 2004). Although the liberalization of the airline industry is often considered a socio-economic success story that has 'democratised' air travel, opened up new regions of the world economy to trade and tourism, and enabled more people to travel to more places more often, concerns about the environmental implications of aviation growth, together with the progressively more 'stressful' and impersonal nature of modern air travel, are increasingly being articulated. Indeed in recent years, airports and conventional passenger air travel have become associated with a range of unpleasant physical and psychological inconveniences including, but not limited to: uncomfortable seats; inedible food; incidents of air rage; lost luggage; boredom; overcrowding; health concerns (particularly relating to deep vein 
thrombosis); confusing baggage restrictions; intrusive security checks; delays; and cancellations (Usborne, 2008; Rosenthal, 2008; Steel, 2007).

In comparison, business operators claim that flying in private aircraft is far less stressful and, as Budd and Hubbard (forthcoming) suggest, the bodily (dis)pleasures associated with conventional forms of aeromobility should be recognised as an important driver of business aviation demand. However, it is only within recent years, following liberalization and the development of new aircraft technology (such as composite airframes, smaller and more fuel efficient jet engines, and increasingly sophisticated aircraft management and auto-flight systems), that such 'superior' forms of aeromobility have become cheaper and easier to access. Thus it is liberalization - among other factors including growth in personal wealth and new technology - that has enabled new ideologies of mobility and the production of new mobile practices.

\section{FIGURE 1 NEAR HERE}

In catering for this demand, according to the 2008 register of business aircraft, currently over 27,690 business aircraft are registered worldwide, up from 25,800 in 2007 . The majority of these aircraft (nearly 72 per cent) are registered in North America, with Europe and South America representing the second and third largest markets respectively (Figure 1). The United States has the largest number of business aircraft registrations, over twice as many as the second largest market, Canada, and nearly 60 times as many as the UK, which represents the tenth largest concentration of business aircraft registrations 
in the world (Figure 2). While the nationality of registration provides an indication of the spatial distribution and likely regions in which business aircraft might be used, many aircraft may actually be registered in one country but predominantly operate out of another, while others may not be registered in the country of their owner's nationality, with islands including Bermuda and the Isle of Man offering business aircraft registration services. Consequently, the country with the largest number of registrations need not automatically correspond to the country with the largest share of business aviation traffic. Indeed, while Germany has the largest number of registrations in Europe, France represents the largest market (with 17.9 per cent of all business aviation departures compared with Germany's 14.9 per cent), and Switzerland exhibits the greatest proportion of business traffic as a share of total air traffic (Marsh, 2006).

FIGURES 2 AND 3 NEAR HERE

\section{The hidden geographies of private business aviation}

The growth of dedicated business aviation can be understood as the result of a complex and interlocking series of supply and demand factors that combine to make flying by private aircraft, for those who can afford it, an attractive and financially viable alternative to premium-class airline travel. The interconnection between liberalization and a burgeoning (if exceedingly difficult to quantify) business aviation market is clearly apparent. But in assessing this trend, we also have to consider the linkages between unintended consequences and technological innovation in further changing the premises and shapes of business models. Private business aviation caters for the most time- 
sensitive and least price-sensitive travellers who pay a premium for the convenience of tailored and flexible flight schedules, the comfort and privacy of a personal aircraft, and the timesavings associated with using smaller, less congested, airports. While small in aggregate terms, it can be assumed to be a very high-yield market although its profitability is less than transparent.

During the late 1970s and early 1980s, a buoyant American economy, combined with rising passenger dissatisfaction with the experience of using scheduled airlines following deregulation, stimulated new interest and demand for business aviation services. While legacy carriers continually sought to refine their business- and first-class products for those travelling on expense accounts (see Coutts Clay, 2003), increasing numbers of passengers were choosing to eschew the airlines for the comfort and convenience of a private aircraft. By 1986, over 80 per cent of the 14,000 business aircraft registered worldwide held US registrations (Sheehan, 2003). In Europe, however, the situation was rather different. Until the mid-1990s, virtually all business travellers in the continent flew in the front end of scheduled flights, as private business aviation was too expensive, too inaccessible, and deemed an unnecessary extravagance that eroded shareholder returns and alienated employees (Crainer and Dearlove, 2001). While this discrepancy might be evidence of a difference in executive compensation between the US and the rest of the world, some sectors of the European business community, in particular, have recently started to reconsider the use of private aircraft and now often regard them as essential business tools that save time, improve employee productivity, and convey corporate prestige (Phillips, 2006). It is too soon to speculate, however, on the repercussions of the 
2008 credit crisis and impending recession. Certainly, there are signs of a downturn in business jet deliveries, which have shown a steady increase since 2003, while overall business-class traffic is expected to decline during 2009 (National Business Travel Association, 2008).

\subsection{The advantages of private business aviation}

Although the cited benefits of business aviation include factors such as: improved time efficiencies; enhanced personal safety; reduction of airport-related 'hassle'; reduced opportunities for industrial espionage; a reduction in the time spent away from home; access to a wider range of airports; and the ability to control flight scheduling and project a positive corporate image; increased employee productivity is often cited as being the most important (Sheehan, 2003; IBAC, 2004). According to the American National Business Aviation Association (NBAA), a trade association who have a strong incentive to promote business aviation, 'Business aircraft are productivity multipliers that allow passengers to conduct business en-route in complete privacy while reducing the stresses associated with travelling on commercial carriers' (NBAA, 2004, p. 3). Passenger surveys have confirmed that employees feel they are significantly more productive aboard business aircraft than they would have been on conventional airlines (or even in their own office). 'Productive collaboration' between clients and staff reportedly occurs between seven and eight times more frequently than on scheduled airlines, while employees were three times less likely to be resting or reading non-work related materials during the flight (NBAA, 2004). 
Often using smaller, less congested airports, passengers may arrive as little as ten minutes before take off, while chauffeurs meet the aircraft on arrival at the destination airport to take clients directly to their meetings or other engagements (Blink, 2008). In addition to being able to fly at short notice, business aviation provides freedom and flexibility from fixed airline schedules and minimum check-in times. Aircraft can be chartered at a few hours' notice and customers can choreograph flight schedules to their personal requirements, enabling them to accomplish in a day what would otherwise require a night away from home:

Pack more cities into a day. Avoid the traffic and the crowds. Fly in and out of airports that are close to your meetings. Work with your team on the flight. Be home in time to kiss the kids goodnight (NetJets, 2008).

The stretching of the fragmentation model to its ultimate form by maximising the ability to fly direct point-to-point services also eliminates the delays associated with lengthy transfers at intermediate hub airports and enables clients to react quickly to new market opportunities and develop relationships with potential new clients before their competitors. These trends clearly intersect with debates surrounding accessibility and the time saving (or time shrinking) effects of different agents of globalisation.

A 2001 study of Fortune 500 companies found operators of business aircraft earned 146 per cent more in cumulative returns than non-operators, and CEOs believed business aircraft helped them identify and execute 'strategic opportunities' for new relationships 
and alliances, as well as reaching important meetings on time, increasing contact with clients, and developing new markets. The NBAA report concluded: 'the bottom line is that business aircraft are good for the bottom line. Business aircraft operators consistently outperform non-operators in key economic performance measures, [including] annual sales volume, number of employees, value of assets, stockholders' equity and annual income' (NBAA, 2004, p. 19). Less tangible benefits, including enhanced personal comfort and convenience, are also cited as being important, but business aircraft are primarily thought of as being 'time-multipliers', that is, they enable companies and individuals to do more things more efficiently (Sheehan, 2003).

\section{2 'Timeshares in the sky' - the rise of fractional jet ownership schemes}

Despite the introduction of new, (relatively) cheaper airframes, private business aircraft remain beyond the financial reach of many corporations. The list price for a Learjet 45 is in the region of $£ 6 \mathrm{~m}$, a Dassault Falcon 2000EX costs nearer $£ 15 \mathrm{~m}$, a Gulfstream 550 no less than $£ 23 \mathrm{~m}$, while a Boeing Business Jet (BBJ) is in excess of $£ 43 \mathrm{~m}$ (Walsh, 2006).

As an alternative to the substantial purchase and running costs associated with owning and operating an aircraft, a new breed of fractional ownership schemes offer companies an alternative entry into private business travel. Fractional operators, such as the US company, NetJets and its subsidiaries, typically finance the purchase of an aircraft and recoup the capital outlay by selling flight time to third parties. Operating as the equivalent of 'aerial timeshares', these schemes allow companies or individuals to buy 
access to a private aircraft for a set number of hours per year, at a fraction of the cost of purchasing the aircraft outright.

The cost of this service varies according to the size and popularity of the desired airframe and the number of flight hours that are required. Clients typically buy a share in an aircraft in 25-hour blocks (or multiples thereof); 25 hours on a seven-seat Citation Bravo retails at around $£ 80,000$, while 50 hours in a 10-seater Dassault Falcon 2000EX costs $£ 800,000$ plus a monthly maintenance fee of $£ 10,000$ (Walsh, 2006). Although additional payments for operating costs, both direct (fuel, maintenance, catering, landing fees, air traffic control charges) and indirect (pilot salaries, pilot training, insurance, administrative support) are also levied (Maslen, 2004), operators stress that the price differential between hiring a private aircraft and travelling in first or business class on a conventional airline is not excessive (Crainer and Dearlove, 2001). By offering a range of aircraft types, fractional operators are able to offer bespoke flight solutions for a wide range of business requirements, from short-haul domestic or European flights, to longhaul transoceanic services. Once an account is opened and a 'flight card' purchased, flights can be booked with as little as 10 hours notice. Aircraft are available 24 hours a day, 365 days a year. In this way, business aviation is creating new discourses of time and convenience, and operators are keen to rehumanise the experience of air travel by offering superior levels of bodily comfort and personal service. Clients are offered the option of ordering customised catering supplies, and limousine or helicopter transfers can be arranged if required. 


\subsection{New innovations and technologies}

In addition to fractional jets, other innovations in private business flight can be identified. There is, for example, mounting anecdotal evidence that helicopters are increasingly being used as vehicles of business mobility (Henley, 2008). New helicopter charter companies, such as Rotorvision, are stressing the practical utility, flexibility, safety, and relatively low(er) costs of hiring helicopters vis-à-vis fixed wing aircraft. Unlike fixed wing aircraft, helicopters are able to operate from unprepared landing sites and require less extensive ground infrastructure and passenger handling facilities. Consequently, they have the potential to fundamentally alter patterns of aeromobility within individual countries by bypassing airports and licensed aerodromes altogether. However, as the majority of these machines land on private sites and fly through uncontrolled airspace, data detailing the scale and spatialities of rotorwing flight is largely non-existent.

Within the fixed-wing business aviation sector, different categories of business aircraft, from large cabin, long-range business jets such as Airbus's A319CJ (based on the A319) and Boeing's Business Jet (based on the B737) to much smaller and lighter airframes, are currently being manufactured (see Table 1).

\section{TABLE 1 NEAR HERE}

At the top end of the market, a new niche for 'VVIP' business aircraft is emerging and Warwick (2006) has commented on an apparent shift in customer requirements from 'corporate' to 'lifestyle' interiors. Airbus has recently revealed an order for an executive 
A380 from a Middle Eastern head-of-state. Featuring a hot tub, Bedouin-style tented lounge, a games room, and en-suite master bedroom, the $£ 225 \mathrm{~m}$ A380VVIP 'superjumbo' will be the largest and most expensive private jet in the sky (Bale, 2007). Such all-inclusive living and working spaces will potentially enable users to fly into a country, conduct their business, and depart without ever having left the aircraft or stepped onto foreign soil.

Here, however, we concentrate on the impact of new aircraft technology on the business aviation sector, namely the VLJ (Very Light Jet), which is, perhaps, the ultimate expression of the fragmentation model. VLJs are the result of recent technological innovations in aircraft and engine design, including the development of lighter airframes, new construction techniques, more sophisticated flight management systems, and more fuel efficient engines. Not only does this make them considerably cheaper to manufacture and purchase, but also cheaper to operate than conventional business jets. Retail prices of between \$1.2-\$3m USD have been cited, compared to over \$20m for a conventional business aircraft (O’Connell, 2008; Sarsfield, 2008a). While proponents claim VLJs will herald a new era of increasingly affordable and accessible private air travel, critics fear they will 'clutter the skies, attract dangerous owner-fliers and degrade the swank-value of private flight' (Brown, 2006, p. 18).

Typically seating between four and seven passengers, VLJs can be flown by a single pilot, have a maximum take off weight of less than $10,0001 \mathrm{~b}(4536 \mathrm{~kg})$, and an average range of around $2000 \mathrm{~km}$. This restricted range precludes their use on coast-to-coast 
services within the United States, and means that sectors between many major world cities, including Madrid-Stockholm, Singapore-Hong Kong, and London-New York, are beyond their effective range. However, unlike existing business aircraft, VLJs can operate from airports with very short runways (as little as 900 metres in length). Theoretically, these performance characteristics should enable VLJs to access thousands of airports that currently cannot be served by jet aircraft (NBAA, 2004) though the costs associated with (re)opening or upgrading airfields for VLJ services should not be underestimated. In 2007, 57 VLJs appeared on international aircraft registers, a figure which had increased to 221 airframes in 2008 (Table 2).

\section{TABLE 2 NEAR HERE}

While emphasising the (relative) affordability of the new generation of VLJs for private purchasers, many of those that have been registered to date have been delivered to air taxi operators seeking to facilitate further fragmentation of the business aviation sector by enabling the development of new business models that undercut the costs of traditional charter programmes. They are reportedly targeting custom from mid-size manufacturing companies, leading technology firms, high-street retailers, and multinational media companies (Sarsfield, 2008b) but the failure in September 2008 of the pioneering US operator, Dayjet, casts doubt on the present feasibility of such concepts. Potentially, however, the introduction of VLJs is likely to further exacerbate fragmentation as airports that previously could not be served by jet aircraft are integrated into the air transport network. The unique operating performance of VLJs means that business travellers can 
access an even greater range of airports, which may be considerably closer to their home, place of work, or intended destination, and reach them far more quickly than ever before.

\subsection{Spatialities of private business aviation: the example of Europe}

To draw out something of the implications of business aviation within the overall context of fragmentation, we now focus on the network geographies of European business aviation. According to the 2007 register of business aircraft, nearly 10 per cent $(2,557)$ of the world's business aircraft are registered in Europe. The sector supports 164,000 jobs and contributes almost $€ 20 \mathrm{bn}$ to the European economy (Sarsfield, 2008c). Since 1986, the numbers of aircraft registered in the continent have increased by over 50 per cent (Sheehan, 2003). 43 European countries had one or more business aircraft on their national registers, but the majority (over 75 per cent) was registered in just eight countries (Table 3).

\section{TABLE 3 NEAR HERE}

There are approximately 1000 business aviation operators trading in Europe but, unlike the scheduled airline industry, most companies have only a small number of aircraft. In 2006, 85 per cent of European business aviation operators had fewer than five aircraft in their fleet while 39 per cent of operators had just one (Marsh, 2006). The largest operator, NetJets Europe, a subsidiary of its US parent, which commenced European operations in 1996, provides services for nearly 1000 separate clients and operates a fleet of over 120 aircraft (Maslen, 2004; Marsh, 2006). In 2005, the company operated 62,000 flights in 
European airspace and recorded 85 per cent growth (Sarsfield, 2006). Owing to the smaller size of their aircraft, NetJets can access over 1000 European airports and over 5000 worldwide, ranging from small airfields to major international airports (Jenvey and Thompson, 2005). While business travellers account for 70 per cent of NetJets European revenue, increasing numbers of private individuals are opting to use their aircraft for 'quality of life' purposes. As competition increases, the market develops, and costs fall, this so-called 'jet for leisure' market is predicted to grow in importance (Doward and Gornitzki, 2005).

According to Eurocontrol data, there are nearly 30,000 airport-pairs in the scheduled European network. These links can be used very intensively, with some, including Barcelona-Madrid, having up to 60 services a day. The business aviation network, in comparison, exhibits a very different geographical pattern in terms of scale, scope, and concentration. In 2005, business aviation operators with smaller aircraft operating from shorter runways and not requiring extensive passenger handling facilities, linked nearly 100,000 European airport-pairs, albeit many being served infrequently (i.e. less than once a week) (Marsh, 2006). Significantly, however, of this total, only five per cent had a scheduled alternative (defined as having at least one scheduled flight per working day) (Jenvey and Thompson, 2005). Whereas the top 500 bi-directional scheduled routes in 2005 accounted for 8,200 movements a day (or 41 per cent of scheduled flights), the corresponding top 500 business routes carried only 500 movements a day (or 29 per cent of business traffic) (Marsh, 2006). 
A key feature of the sector is that business aircraft fly where and when they are needed and do not operate to timetables that oblige them to operate even when half empty. While a significant portion of business traffic occurs between a few key city-pairs that are well served by scheduled airlines, factors such as customer demand and issues of airport access and cost (particularly at major hubs like London Heathrow and Paris Charles de Gaulle) mean that business aircraft usually serve the so-called 'reliever airports' in major metropolitan areas (NBAA, 2004). For example, business operators may fly into Paris Le Bourget as opposed to Charles de Gaulle, and London Farnborough or Biggin Hill in preference to Heathrow (significantly, business aviation traffic only accounts for more than three per cent of the total traffic at only two of Europe's top ten busiest airports) (Marsh, 2006). Business operators and customers prefer using these reliever airports, as they are smaller, less congested, offer rapid security clearance, do not suffer from slot restrictions, and are considered more personal. However, there are limits to the number of airports than can be used. Only 11 per cent of the 1178 European airports that are physically capable of accepting business aircraft have the necessary ground infrastructure (such as hangers, refuelling facilities and customs inspection points) to support aircraft turnarounds, and present levels of traffic often do not justify the investment that would be required (Marsh, 2006). While it could be argued that the use of reliever airports alleviates congestion at major hubs, business aviation may simply serve to spread airspace congestion and subject more people to aircraft noise as smaller airfields are developed for use by business flights (Clark, 2006). London/Farnborough and London/Biggin Hill, for example, have developed into major year-round business aviation centres with dedicated passenger terminals and maintenance hangers, while 
others have become the destination of choice during major sporting fixtures or cultural events (Marsh, 2006).

The networks flown by business aircraft comprise the 'purest' form of fragmentation, being direct, point-to-point services which generate significant time savings. In contrast to the concentration of scheduled airline traffic, business aviation is a small market spread thinly. In 2005, more than half of business traffic originated from airports with fewer than 50 IFR (instrument flight rules) departures a day. In terms of airport and citypairs, business aviation is significantly different from scheduled traffic. It 'is not about taking passengers from the front end of a scheduled flights and flying them in their own aircraft...Business aviation fills a gap in scheduled services: most business flights are between cities not served by scheduled flights' (Marsh, 2006, p. 4, original emphasis). Thus, while the full-service scheduled airline network is concentrated on capital cities and major metropolitan regions, the business aviation network is more diffuse. 'Just as business aviation links airports that scheduled aviation does not...it also serves distances over which scheduled traffic, with its fixed timetables and extended check-in times, can not practibly [sic] serve' (Marsh, 2006, p. 34). While business aviation does have its share of long-haul flights, only nine per cent of business flights are over $2000 \mathrm{~km}$ long. Most are shorter than the average scheduled flight, with the commonest length being 300 400km (Ibid., 2006).

Clearly, there are environmental and other externalities involved here. As traffic grows, this will increase congestion and air traffic complexity in Europe's already densely 
trafficked airspace but as Calder (2006, p. 3) notes, as in the United Kingdom, taxation on air travel, ostensibly for environmental reasons, 'actually makes the use of [exempt] executive jets a more rational choice for business travellers'. In a further contradiction in climate policy, private jets under 5,700kg will not be liable under the European Emissions Trading Scheme, which is designed to make the industry pay for the environmental damage it causes.

\section{Conclusion}

Crang (2002) and Urry (2007), among others, have highlighted the highly inequitable nature of global air travel and shown how the enhanced mobility enjoyed by some members of the aeromobile elite is frequently achieved at the expense of other travellers. In recognition of the 'hassle' associated with much modern air travel, new operators are seeking to reclaim some of the 'glamour' previously associated with air travel and have developed new 'lifestyle' solutions to cater for the needs of wealthy aeromobile travellers. In addition to being used for business purposes, evidence suggests that increasing numbers of people are choosing to fly on business aircraft for 'quality of life' purposes, and as costs fall this so-called 'jet for leisure' market is predicted to grow in importance (Doward and Gornitzki, 2005; Walsh, 2006). Despite the credit crisis, the phenomenon of private business aviation is also likely to spread to other global markets. There is already evidence of an emerging market in China (Sobie, 2006; Perrett, 2007); business flights to and from Russia are becoming increasingly frequent (Sarsfield, 2006); and demand for business aviation is likely to grow in the dynamic economies of the Middle East, India, and parts of south-east Asia, though different regulatory regimes will ultimately affect how these markets develop. 
In terms of unintended consequences, the burgeoning private aviation sector seems a long way from the intentions of the legislators who have promoted liberalization as a means of creating a more competitive global air transport industry (albeit within the constraints of their own national interests). While the emphasis of policy has been on scheduled air travel, the dynamics of air transport demand, which are in turn, linked to geographies of affluence and globalisation, have led to the provision of air travel materialising in different and unintended ways. The apparent insatiable long-term upward trajectory in the global demand for private business air travel and the introduction of new technologies that facilitate the ability of suppliers to satisfy and grow that demand provide mounting evidence that liberalization is leading to even more enhanced degrees of fragmentation. This applies in both meanings of the term: an escalation in the number of point-to-point routes in terms of volume and also the actual number of city- and airport-pairs; and to an enhanced degree of market segmentation as the affluent and 'super rich' increasingly opt out of the negativities of the scheduled, liberalised market, evermore a victim of its own success. Point-to-point services permit travellers to overfly congested and timeconsuming hubs that result from an integrated network airline strategy and avoid the unpleasantries of low-cost airline travel - the first and second revolutionary outcomes of liberalization. The growth and elaboration of the models for both dedicated scheduled and private business air travel may suggest a third stage of liberalization, defined by a separator strategy that, to put it bluntly, allows, for a more secure form of social segregation in air travel for those sufficiently affluent to afford it (or sufficiently important to have someone else pay for it). 


\section{References}

Adey, P., Budd, L. C. S. and Hubbard, P. J. 2007. Flying lessons: exploring the social and cultural geographies of global air travel. Progress in Human Geography 31(6), 773791.

Bale, J. 2007 The flying palace that's fit for a king who has no qualms about his carbon footprint. The Times 30.03.2007, 29.

Barclaycard 2006. The Barclaycard Business Travel Survey 2005/06. Nottingham, Barclaycard Business and Future Foundation.

Beaverstock, J. V., Derudder, B., Faulconbridge, J. and Witlox, F. forthcoming. Business travel in the global economy. In: Beaverstock, J. V., Derudder, B., Faulconbridge, J. and Witlox, F. (Eds.), Business Travel in the Global Economy. Ashgate, Aldershot.

Blink 2008. www.flyblink.com, last accessed 11.07.2008.

Bowen, J. 2002. Network change, deregulation, and access in the global airline industry. Economic Geography 78(4), 425-439.

Brown, H. 2006. The height of indulgence. The Independent 01/07/2006, 18-19.

Budd, L. C. S. and Hubbard, P. J. forthcoming. The bizjet set: business aviation and the new geographies of private flight. In: Beaverstock, J. V., Derudder, B., Faulconbridge, J. and Witlox, F. (Eds.), Business Travel in the Global Economy. Ashgate, Aldershot.

Calder, S. 2006. How the law of unintended consequences applies to air travellers. The Independent Traveller 09/12/2006, 3 .

Cessna Corporate Website. 2008. www.cessna.com Accessed 12.11.2008. 
Clark, A. 2006. Business travellers switch to private jets. The Guardian 05.05.2006, 26.

Coutts Clay, J. 2003. Jetliner Cabins. Chichester, John Wiley and Sons.

Crainer, S. and Dearlove, D. 2001. The Financial Times Guide to Business Travel.

London, Financial Times/Prentice Hall.

Crang, M. 2002. Between places: producing hubs, flows, and networks. Environment and Planning A 34, 569-574.

Croft, J. 2008. Bolder Big Brother. Flight International. 13-19 May 2008, 64-67.

Derudder, B. and Witlox, F. 2008. Mapping world city networks through airline flows: context, relevance, and problems. Journal of Transport Geography 16, 305-312.

Doganis, R. 1994. The impact of liberalization on European airline strategies and operations. Journal of Air Transport Management 1(1), 15-25.

Doward, J. and Gornitzki, D. 2005. Tourists take private jets to beat queues. The Observer 31/07/2005, 6 .

Embraer Executive Jets Corporate Website. 2008. www.embraerexecutivejets.com Accessed 12.11.2008.

Flight International. 2008. Lufthansa's private jet set. 18-24 March, 24.

Gates, B. 2007. jp Biz-jet and Turboprops. Reigate, Surrey, BUCHair (UK) Ltd.

Gates, B. 2008. jp Biz-jet and Turboprops including VLJs. Reigate, Surrey, BUCHair (UK) Ltd.

Goetz, A. R. and Graham, B. 2004. Air transport globalization, liberalization and sustainability: post-2001 policy dynamics in the United States and Europe. Journal of Transport Geography 12(4), 265-276.

Graham, B. 1995. Geography and Air Transport. Wiley, Chichester. 
Graham, B. and Shaw, J. 2008. Low-cost airlines in Europe: reconciling liberalization and sustainability. Geoforum 39, 1439-1451.

Grant, R. G. 2003. Flight: 100 Years of Aviation. London, Dorling Kindersley.

Henley, J. 2008. Choppermania: Why helicopters are booming. The Guardian G2 31.01.2008, 4-7.

IATA 2007. World Air Transport Statistics Digest and Key Performance Indicators. Montreal, IATA.

IBAC 2008. www.ibac.com Last accessed 11/07/2008.

Jenvey, M. and Thompson, C. 2005. NetJets - a unique safety challenge: focus on commercial aviation safety. United Kingdom Flight Safety Committee Issue 60, Autumn, 19-23.

Lawton, T. 2002. Cleared for Take-off Structure and Strategy in the Low Fare Airline Business. Aldershot, Ashgate.

Lee, H-S. 2008. The networkability of cities in the international air passenger flows 1992-2004. Journal of Transport Geography (forthcoming).

Lindstädt, H. and Fauser, B. 2004. Separation or integration? Can network carriers create distinct business streams on one integrated production platform? Journal of Air Transport Management, 10(1), 23-31.

Marsh, D. 2006. Getting to the Point: Business Aviation In Europe. Eurocontrol: Trends in Air Traffic. Volume 1. Brussels, Eurocontrol.

Maslen, R. 2004. NetJets Supporting the Business Community, Airliner World February, $34-37$. 
National Business Travel Association 2008. Business Travel Overview and Cost Forecast 2009, http://www.nbta.org/Research/Surveys/, accessed 18.11.2008.

NBAA 2004. NBAA Business Aviation Fact Book. Washington DC, NBAA.

NetJets 2008. www.netjets.com Last accessed 11/07/2008.

O'Connell, D. 2008. Cheap jets lift private aviation. The Sunday Times Business Supplement 03/02/2008, 8 .

Perrett, B. 2007. Ready to Blossom: China is opening up to business aviation. Aviation Week and Space Technologby 166(8) February $19^{\text {th }}, 45$.

Phillips, E. H. 2006. The future of business aviation in Europe is bright, Aviation Week and Space Technology, 165(14), October 9, 56.

Robertson, D. 2008. Eos flight into trouble signals end to cheap executive travel. The Times 28/04/2008, 34 .

Rosenthal, E. 2008. Europe's worst airports? So many to choose from. The New York Times with The Observer 09/03/2008, 6 .

Sarsfield, K. 2006. The New Frontier. Flight International (Business Aviation Special) 5057(170) 10-16 October, 46-49.

Sarsfield, K. 2008a. What crisis? Business aviation focus. Flight International 13-19 May, 34-45.

Sarsfield, K. 2008b. Hail to the air taxi. Flight International 13-19 May, 46-49. 
Sarsfield, K. 2008. European business aviation contributes $€ 20 \mathrm{bn}$ to economy: study Flight International 01.12.2008. Retrieved from www.flightglobal.com/articles/2008/12/01/319570 on 01/12/2008.

Schumer, C. E. and Maloney, C. B. 2008. Your flight has been delayed again. Report by the U.S. Joint Economic Committee May.

Shaw, S. 2004. Airline Marketing and Mangement (fifth edition). Aldershot: Ashgate.

Sheehan, J. J. 2003. Business and Corporate Aviation Management. On-demand Air Travel. New York, McGraw-Hill Professional.

Smith, D. A. and Timberlake, M. 1995. Conceptualising and mapping the structure of the world system's city system. Urban Studies 32 (2), 287-302.

Sobie, B. 2006. China seeks to encourage growth. Flight International 5028(169) March, $21-27$

Steel, M. 2007. Why can't we stop flying when it's such torture? The Independent 19/12/2007, 31 .

Turner, L. 2004. We'll all soon beg to fly business. Financial Times Weekend Edition July $10^{\text {th }}-11^{\text {th }}, 17$.

Urry, J. 2007. Mobilities. Polity Press, Cambridge.

Usborne, D. 2008. Travellers fly into clouds of misery. The Independent 23/06/2008, 25.

Walsh, C. 2006. Private jets lose air of exclusivity. The Observer Business and Media 23/04/2006, 6 .

Warwick, G. 2006. Size sells. Flight International 5037(169) 23-29 May, 30-31.

Werdigier, J. 2008. Silverjet grounded as funds dry up. International Herald Tribune 31 May-1 June 2008, 1 and 24. 
Zook, M. A. and Brunn, S. D. 2005. Regions, hierarchies and legacies: European cities and global air travel. Journal of Contemporary European Studies 13(2), 203-220.

Zook, M. A. and Brunn, S. D. 2006. From Podes to Antipodes: positionalities and global airline geographies. Annals of the Association of American Geographers 96(3), 471490. 